\title{
ANALISIS PENGARUH PEMAHAMAN MODUL PENERIMAAN NEGARA (MPN) TERHADAP TINGKAT KEPATUHAN WAJIB PAJAK PADA KPP PRATAMA KEDATON
}

(Study Kasus pada KPP Pratama Kedaton)

\author{
Khomsiyah, Universitas Trisakti \\ Rico Yanuar, Universitas Bandar Lampung \\ Rosmiaty Tarmizy, Universitas Bandar Lampung
}

\begin{abstract}
The purpose of this study was to analyze the influence of the understanding module of State Revenue (MPN) on the level of tax compliance on STO Kedaton. Based on the analysis of the answers to the questionnaire, the level of understanding of the corporate taxpayers Module Revenues (MPN) of 73.3\% and is in the category understand.

While the level of tax compliance on STO Kedaton at $71.1 \%$ and is in the category submissive. Despite this level of understanding of the taxpayer Module Revenues (MPN) and the level of tax compliance on STO Kedaton not yet reached optimal levels. This is because the government lacks in socializing Module Revenues $(M P N)$. Besides the lack of government in delivering superior service to taxpayers and given sanctions still looks less than the maximum, giving rise to a lack of tax compliance in paying taxes.

Based on the analysis results, the authors suggest to STO Kedaton to improve socialization MPN MPN for taxpayers because it can provide a substantial contribution to improving taxpayer compliance in paying taxes. Furthermore, it provides strict penalties for taxpayers who "naughty" and provide better service tax for taxpayers so that taxpayers can feel easy and comfortable in paying taxes. For further research to develop this research further.
\end{abstract}

Keywords : Module State Revenue, Level Of Compliance, Taxpayer

\section{LATAR BELAKANG}

Pembangunan sebuah negara tak lepas dari keteraturan pengelolaan keuangan negara. Sesuai dengan amanat Undang-Undang, tugas pengelolaan keuangan Negara diemban oleh Departemen Keuangan dimana realisasi penerimaan dan pengeluaran kas negara berada di bawah Direktorat Jenderal Perbendaharaan.

Pada saat dimana fasilitas perbankan belum dimanfaatkan, penerimaan dan pembayaran dana negara dikelola oleh Departemen Keuangan melalui Kantor Kas Negara sepenuhnya. Kantor Kas Negara inilah yang menerima setoran pajak maupun non-pajak, serta membayarkan gaji pegawai negeri maupun kewajiban pada rekanan negara. Sementara, di sisi lain, penyetor pajak dan bukan pajak harus datang ke Kantor Kas Negara untuk mengisi formulir dan melakukan pembayaran. Sejak tahun 1988, pola penyetoran dana negara kemudian berubah dengan penerapan Giralisasi dimana Departemen Keuangan mulai menggunakan jasa perbankan dalam proses penyetoran dana negara. 
Di akhir tahun 1990-an sistem ini kemudian dilengkapi dengan teknologi komputerisasi yang sifatnya stand alone terpisah dari sistem komputerisasi bank yang digunakan jasanya oleh Departemen Keuangan. Sistem pencatatan yang dikembangkan ini disebut Sistem Penerimaan Negara atau SISPEN. Pada masa itu yang mengelola adalah Direktorat Jenderal Anggaran. Sementara, pada periode yang kurang lebih sama. Direktorat Jenderal Pajak mengembangkan sistem Monitoring Pelaporan Pembayaran Pajak atau MP3. Direktorat Jenderal Bea dan Cukai mengembangkan Sistem Electronic Data Interchange (EDI) untuk melayani kalangan eksportir maupun importir.

\section{TELAAH LITERATUR DAN PENGEMBANGAN HIPOTENSI}

\subsection{Pengertian Modul Penerimaan Negara}

Modul Penerimaan Negara atau disingkat MPN, adalah modul penerimaan yang memuat serangkaian prosedur mulai dari penerimaan, penyetoran, pengumpulan data, pencatatan, pengikhtisaran, sampai dengan pelaporan yang berhubungan dengan penerimaan negara dan merupakan bagian dari Sistem Perbendaharaan dan Anggaran Negara. Sebagai suatu implementasi e-Government, Modul Penerimaan Negara merupakan suatu kebijakan Pemerintah yang ditujukan untuk melakukan pencatatan penerimaan negara. MPN ini merupakan suatu terobosan yang dilakukan oleh Departemen Keuangan dimana merupakan sistem yang terintegrasi dengan sistem perbankan dan dengan adanya Central Database di Departemen Keuangan sehingga memungkinkan kemudahan akses tentang penerimaan negara oleh instansi-instansi terkait di lingkungan Departemen Keuangan. Modul Penerimaan Negara (MPN) merupakan suatu sistem yang mengintegrasi tiga sistem penerimaan yang selama ini berjalan, yaitu sistem Monitoring Pelaporan Pembayaran Pajak (MP3) oleh Direktorat jenderal Pajak, Sistem Elektronik Data Intercharge (EDI) oleh Direktorat Jenderal Bea dan Cukai, dan Sistem Penerimaan Negara (SISPEN) oleh Direktorat Jenderal Anggaran.

Dasar hukum digunakannya modul ini adalah Peraturan Menteri Keuangan Nomor 99/PMK.06/2006 tanggal 19 Oktober 2006 tentang Modul Penerimaan Negara (MPN) yang berlaku mulai tanggal 1 Januari 2007, Peraturan Dirjen Perbendahaan Nomor PER78/PB/2006 tanggal 27 Desember 2006 tentang Penatausahaan Penerimaan Negara melalui Modul Penerimaan Negara dan Peraturan Dirjen Pajak Nomor PER-148/PJ/2007 tentang pelaksanaan Modul Penerimaan Negara.

Dalam Peraturan Menteri Keuangan tentang Ketentuan Umum pasal 1 ayat (1) disebutkan sebagai berikut: "Modul Penerimaan Negara adalah modul penerimaan yang memuat serangkaian prosedur mulai dari penerimaan, penyetoran, pengumpulan data, pencatatan, pengikhtisaran sampai dengan pelaporan yang berhubungan dengan penerimaan negara dan merupakan bagian dari Sistem Penerimaan dan Anggaran Negara."

\subsection{Manfaat Penerapan Modul Penerimaan Negara}

Bagi Departemen Keuangan sangat jelas sekali terasa manfaat dari diberlakukannya Modul Penerimaan Negara ini. Berikut beberapa manfaat yang diperoleh dari MPN:

- Ruang Lingkup MPN yang luas meliputi Penerimaan Perpajakan, Penerimaan Negara Bukan Pajak (PNBP), Penerimaan Pengembalian Belanja, dan Penerimaan Perhitungan Pihak Ketiga yang disetor oleh perorangan/badan dan/atau Bendahara melalui Bank Persepsi/Devisa Persepsi/Pos Persepsi dan penerimaan yang berasal dari Surat Perintah Membayar (SPM) yang dibukukan oleh Kantor Pelayanan Perbendaharaan Negara (KPPN), menjadikan pengelolaan keuangan negara lebih mudah dilakukan. 
- Secara teknis pengelolaan keuangan negara menjadi lebih efektif dan efisien karena menggunakan sistem yang sama antara penerimaan dari Pajak, Bea Cukai serta sistem pencatatan oleh perbendaharaan. berikut :

Bagi masyarakat manfaat dari diberlakukannya Modul Penerimaan Negara sebagai

- Adanya kemudahan, karena MPN adalah layanan setoran on-line selama 24 jam yang dapat dilakukan dari mana saja serta fleksibel karena dapat dilakukan melalui berbagai fasilitas pembayaran pada bank/pos.

- Adanya kepastian yang diperoleh oleh Wajib Pajak/Bayar dengan mendapat kode penomoran yang unik dan khusus untuk setiap transaksi, menjamin validitas dan akurasi transaksi penerimaan serta monitoring penerimaan negara dapat dilakukan secara real-time.

\subsection{Kelebihan dan Kemudahan Modul Penerimaan Negara}

Modul Penerimaaan Negara merupakan integrasi dari beberapa sistem yang ada di lingkungan Departemen Keuangan, secara garis besar kelebihan dan kemudahan yang ditawarkan oleh Modul Penerimaan Negara sebagai suatu sistem yang telah terintegrasi adalah sebagai berikut:

- MPN sebagai satu-satunya yang terintegrasi dengan Banking System bila dibandingkan dengan sistem lama terdapat tiga sistem yang berbeda yaitu SISPEN, MP3 dan EDI dimana satu transaksi tercatat harus di-input kedalam ketiga sistem tersebut.

- Pelayanan yang diberikan pada sistem MPN, bank hanya merekam satu kali transaksi dengan waktu operasi yang tidak terbatas.

- Autentikasi transaksi pada MPN dilakukan pada semua jenis setoran baik pajak maupun bukan pajak termasuk potongan SPM dalam bentuk Nomor Transaksi Penerimaan Pajak (NTPN), sedangkan pada sistem lama autentikasi transaksi hanya dilakukan pada setoran pajak saja melalui sistem MP3 dalam bentuk Nomor Transaksi Penerimaan Pajak (NTPP).

- Rekonsiliasi pada MPN mudah dilakukan berbekal pada identitas NTPN yang unik dan tingkat validitas data tinggi.

- Distribusi data penerimaan dilakukan oleh DJPBN secara elektronik (real time) ke DJP, DJAPK, DJBC dan unit terkait lainnya.

- $\quad$ MPN menganut sistem sentralisasi untuk pengolahan data.

- Pengawasan pada MPN dapat dilakukan setiap saat dan tidak terbatas pada tempat, sesuai dengan kewenangan masing-masing instansi/pemakai.

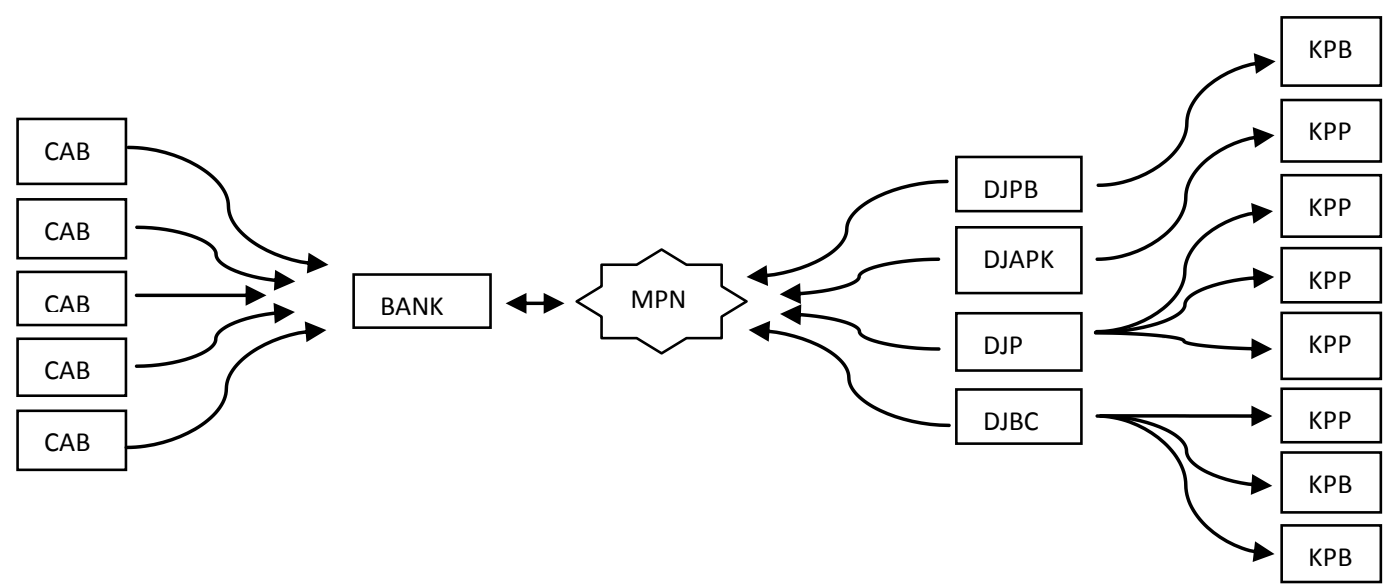

Gambar I : Mekanisme Modul Penerimaan Negara 


\subsection{Konsep Pemahaman}

Menurut Kamus Lengkap Bahasa Indonesia (Amran, 2002:427) Pemahaman adalah sesuatu hal yang kita pahami dan kita mengerti dengan benar. Pemahaman menurut Sadiman (1946:109) adalah suatu kemampuan seseorang dalam mengartikan, menafsirkan, menerjemahkan, atau menyatakan sesuatu dengan caranya sendiri tentang pengetahuan yang pernah diterimanya. Sedangkan menurut Suharsimi (2009:118) menyatakan bahwa pemahaman (comprehension) adalah bagaimana seorang mempertahankan, membedakan, menduga (estimates), menerangkan, memperluas, menyimpulkan, menggeneralisasikan, memberikan contoh, menuliskan kembali, dan memperkirakan.

\subsection{Konsep Kepatuhan}

Menurut Kamus Besar Bahasa Indonesia (Pranoto, 2007:122), patuh adalah suka menurut perintah, taat pada perintah, sedangkan kepatuhan adalah perilaku sesuai aturan dan berdisiplin. Sarafino (1990:138) dikutip oleh (Slamet B, 2007:140), mendefinisikan kepatuhan (ketaatan) sebagai tingkat penderita melaksanakan cara pengobatan dan perilaku yang disarankan oleh dokter atau orang lain. Kepatuhan juga dapat didefinisikan sebagai perilaku positif penderita dalam mencapai tujuan terapi (Degresi, 2005:98).

\subsection{Kepatuhan Perpajakan}

Kepatuhan perpajakan (tax compliance) dapat didefinisikan sebagai suatu sikap/perilaku wajib pajak yang melaksanakan semua kewajiban perpajakannya dan menikmati semua hak perpajakannya sesuai dengan ketentuan peraturan perundangan yang berlaku.

Kepatuhan wajib pajak dikemukakan oleh E. Eliyani yang dikutip dari Kiryanto (1997:7), menyatakan bahwa "Kepatuhan wajib pajak didefinisikan sebagai memasukan dan melaporkan pada waktunya informasi yang diperlukan, mengisi secara benar jumlah pajak yang terutang, dan membayar pajak pada waktunya tanpa adanya pemeriksaan. Ketidak patuhan akan timbul apabila ada salah satu definisi tersebut tidak terpenuhi.

Menurut Norman D. Nowak dikutip dari (Moh. Zain, 2004:86) kepatuhan Wajib Pajak sebagai suatu iklim kepatuhan dan kesadaran pemenuhan kewajiban perpajakan, tercermin dalam situasi dimana:

1. Wajib Pajak paham atau berusaha untuk memahami semua ketentuan peraturan perundang-undangan perpajakan.

2. Mengisi formulir pajak dengan lengkap dan jelas.

3. Menghitung jumlah pajak yang terutang dengan benar.

4. Membayar pajak yang terutang tepat pada waktunya.

Menurut Keputusan Menteri Keuangan No. 544/KMK. 04/2000, bahwa kriteria kepatuhan Wajib Pajak adalah:

- Tepat waktu dalam penyampaian SPT untuk semua jenis pajak dalam 2 tahun terakhir.

- Tidak mempunyai tunggakan pajak untuk semua jenis pajak, kecuali telah memperoleh izin untuk mengangsur atau menunda pembayaran pajak.

- Tidak pernah dijatuhi hukuman karena melakukan tindak pidana di bidang perpajakan dalam jangka waktu 10 tahun terakhir.

- Dalam 2 tahun terakhir menyelenggarakan pembukuan dan dalam hal terhadap Wajib Pajak pernah dilakukan pemeriksaan, koreksi pada pemeriksaan yang terakhir untuk masing-masing jenis pajak terutang paling banyak $5 \%$. 
- Wajib Pajak yang laporan keuangannya untuk 2 tahun terakhir diaudit oleh Akuntan Publik dengan pendapat wajar tanpa pengecualian, atau pendapat dengan pengecualian sepanjang tidak mempengaruhi laba rugi fiscal.

Menurut Safri Nurmantu (2003:148), ada dua macam kepatuhan yakni kepatuhan formal dan kepatuhan materiil. Kepatuhan formal adalah suatu keadaan dimana Wajib Pajak memenuhi kewajiban perpajakan secara formal sesuai dengan ketentuan formal dalam undang-undang perpajakan, yaitu:

- Melaporkan SPT tepat waktu (pasal 3 ayat 3 UU no. 28 tahun 2007) : Melaporkan SPT Tahunan pajak penghasilan wajib pajak badan paling lambat 4 (empat) bulan setelah akhir tahun pajak.

- Melaporkan usahanya ke Direktorat Jenderal Pajak (pasal 2 ayat 2 UU no. 2008 tahun 2007) : melaporkan usahanya agar usahanya tersebut terdaftar di kantor pelayanan pajak sesuai dengan wilayahnya.

- Melampirkan laporan keuangan berupa neraca dan laporan laba rugi serta keterangan lain yang digunakan untuk menghitung besarnya pajak penghasilan (pasal 4 ayat 4 no. 28 tahun 2007) : melampirkan laporan keuangan agar mempermudah dalam penghitungan besarnya pajak penghasilan.

- Pengurus atau direksi menandatangani surat pemberitahuan wajib pajak badan (pasal 4 ayat 2 no. 28 tahun 2007) : surat pemberitahuan ditandatangani oleh pengurus atau direksi agar dapat dipertanggungjawabkan.

- Melunasi pajak yang masih terutang setelah menerima surat tagihan pajak atau SKPKB tepat waktu (pasal 9 ayat 3 UU no. 28 tahun 2007) : wajib pajak badan melunasi pajak yang masih terutang 1 bulan setelah diterbitkannya surat tagihan pajak atau SKPKB.

- Wajib pajak badan melakukan pembetulan surat pemberitahuan tahunan yang telah disampaikan sebelumnya (pasal 8 ayat 6 UU no. 28 tahun 2007) : melakukan pembetulan atau koreksi setelah menerima surat ketetapan pajak sebelumnya.

Wajib pajak yang berperilaku sekedar memenuhi kepatuhan formal mempunyai peranan yang besar terhadap rendahnya coverage ratio (angka yang menunjukkan perbandingan antara jumlah pajak yang terpungut dan jumlah potensi pajak mestinya dapat dipungut) pajak penghasilan di Indonesia yang menurut pengamatan sementara baru berkisar antara $35 \%$. Sebaliknya wajib pajak yang berperilaku memenuhi kepatuhan materiil mempunyai peranan yang besar dalam mempertinggi coverage ratio. Kepatuhan dapat diwujudkan misalnya dengan penyuluhan, pelayanan, dan penegakan hukum yang dapat berupa pemeriksaan, penyidikan, dan penagihan dengan menempatkan wajib pajak sebagai subjek yang dihargai hak-hak dan kewajibannya. Tingkat kepatuhan wajib pajak yang dimaksud dalam hal ini adalah kepatuhan wajib pajak efektif dalam pemenuhan kewajiban perpajakannya.

Ada beberapa faktor yang menentukan tinggi rendahnya kepatuhan perpajakan, antara lain kejelasan (clarity) undang-undang dan peraturan pelaksanaan perpajakan, besarnya biaya kepatuhan, (compliance cost) dan adanya panutan.Adanya ketidakpatuhan secara bersamaan dapat menimbulkan upaya menghindarkan pajak secara melawan hukum atau tax evasion.

Tax evasion adalah perbuatan melanggar undang-undang. Misalnya menyampaikan di dalam SPT jumlah penghasilan yang lebih rendah daripada yang sebenarnya (understatement of income) di satu pihak dan atau melaporkan biaya yang lebih besar daripada yang sebenarnya (overstatement of the deductions) di lain pihak. Bentuk tax evasion yang lebih parah adalah apabila Wajib Pajak sama sekali tidak melaporkan penghasilannya (nonreporting of income). 


\subsection{Kerangka Pemikiran}

Modul Penerimaan Negara (MPN) sebagai suatu sistem yang digagas oleh Departemen Keuangan merupakan suatu sistem yang terintegrasi dengan sistem perbankan dan dengan adanya central database memungkinkan kemudahan akses tentang penerimaan negara oleh instansi-instansi terkait di lingkungan Departemen Keuangan. Selain itu, MPN juga mengintegrasikan tiga sistem penerimaan yang selama ini berjalan, yaitu Sistem Monitoring Pelaporan Pembayaran Pajak (MP3) oleh Direktorat Jenderal Pajak, Sistem Electronic Data Interchange (EDI) oleh Direktorat Jenderal Bea dan Cukai dan Sistem Penerimaan Negara (SISPEN) oleh Direktorat Jenderal Anggaran sehingga para pelaku pembayaran yang sebelumnya terkait dengan ketiga sistem di atas diharapkan akan semakin dipermudah dengan adanya penerapan sistem baru ini khususnya bagi pembayaran Pajak.

Kondisi perpajakan yang menuntut keikutsertaan aktif wajib pajak dalam menyelenggarakan perpajakannya membutuhkan kepatuhan wajib pajak yang tinggi. Dalam hal wajib pajak tentu dengan adanya modul ini akan memudahkan wajib pajak dalam melakukan kewajibannya karena modul ini dapat membuat wajib pajak membayar pajak dimana saja dan sifat real time dari modul ini memungkinkan transaparansi keuangan negara yang lebih optimal karena siapapun dapat melakukan pemantauan secara reguler. Sehingga dengan pemahaman wajib pajak akan modul ini diharapkan dapat meningkatkan tingkat kepatuhan wajib pajak dalam melakukan kewajiban pembayaran pajak sehingga penerimaan pajak dapat optimal.

Berdasarkan kerangka pemikiran yang dikemukakan diatas dapat disimpulkan model penelitian sebagai berikut:

\begin{tabular}{|ll|}
\hline & Pemahaman MPN \\
\hline - Keakuratan \\
- Ketepatan \\
- Relevansi \\
$\therefore$ Dapat dipercaya \\
- Kemudahan \\
\hline
\end{tabular}

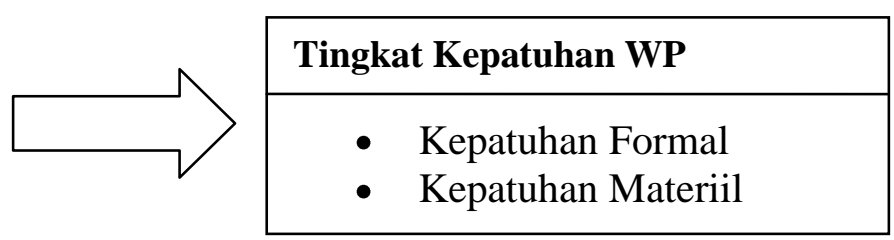

\section{METODOLOGI PENELITIAN}

\subsection{Objek Penelitian}

Objek penelitian yang diambil oleh peneliti adalah Kantor Pelayanan Pajak Pratama Kedaton yang terletak di Jalan Dr. Susilo no. 41 Bandar Lampung. Sedangkan populasinya adalah seluruh wajib pajak badan yang terdaftar di Kantor Pelayanan Pajak Pratama Kedaton tahun 2011 sebesar 5.538 wajib pajak badan. Dalam hal ini sampel yang akan diambil adalah 5 wajib pajak badan besar yang mewakili keseluruhan dari wajib pajak badan yang terdaftar di Kantor Pelayanan Pajak Pratama Kedaton yaitu Candi Mas Jaya Keramik, PT. Persada Lampung Raya, KFC Kedaton, United Tractor, Tribun Lampung yang di ambil dengan cara purposive sampling dengan jenis judgement sampling. Sehingga di dapat sampel sebanyak 35 responden. 


\section{Sumber Data dan Jenis Data}

Dalam Penelitian ini peneliti menggunakan data primer dan data sekunder. Data primer ini merupakan data yang diperoleh secara langsung dari objek penelitian dengan cara kuesioner. Sedangkan data sekunder merupakan data yang tidak langsung diperoleh dari objek penelitian. Dalam hal ini data sekunder dapat berupa data diri karyawan (usia, jenis kelamin) serta lama masa kerja.

\subsection{Metode Pengumpulan Data}

Penulis mengadakan penelitian langsung terhadap objek yang berkaitan dengan penyusunan skripsi ini guna mendapatkan data yang dapat dipercaya dan untuk mengetahui secara konkret keadaan objek penelitian tersebut. Penelitian yang dilakukan adalah dengan cara:

a. Penelitian Kepustakaan (Library Research)

Yaitu penelitian yang diarahkan untuk pengumpulan landasan teori yang akan digunakan dalam melakukan analisa. Dimana penelitian ini dilakukan dengan mempelajari literature dan sumber-sumber pustaka lainnya yang berkaitan dengan penelitian.

b. Penelitian Lapangan (Field Research).

Yaitu penelitian yang dilakukan dengan cara kunjungan langsung objek penelitian. Adapun dengan teknik pengumpulan data sebagai berikut:

1. Wawancara (interview)Peneliti akan melakukan wawancara dengan pegawai di Kantor Pelayanan Pajak Pratama kecamatan Kedaton yang diperkirakan dapat memberikan informasi atas keperluan penelitian. Jenis wawancara yang akan dilakukan adalah Focus Interview.

2. Dokumentasi

Tehnik pengumpulan data dengan cara melihat dan mencatat berbagai dokmen catatan, laporan dari objek penelitian yang sesuai dengan topik/permasalahan yang ada.

3. Teknik pengumpulan data dengan cara memberikan daftar pertanyaan dengan bobot nilai yang kemudian diisi oleh responden.

\section{Operasional Variabel dan Pengukuran Variabel}

Operasional variabel menjelaskan variabel-variabel sesuai dengan fungsi atau kedudukan sebagai variabel independent $(\mathrm{X})$ dan variabel dependent $(\mathrm{Y})$. Pada penelitian ini yang merupakan variabel independent $(\mathrm{X})$ adalah pemahaman Modul Penerimaan Negara (MPN), sedangkan variabel dependent (Y) adalah tingkat kepatuhan wajib pajak dengan indikator-indikator sebagai berikut:

a. Pemahaman Modul Penerimaan Negara yang ditekankan pada:

1. Keakuratan

2. Ketepatan

3. Relevansi

4. Dapat dipercaya

5. Kemudahan

6. Efisiensi

b. Tingkat kepatuhan wajib pajak yang dibagi menjadi 2 macam kepatuhan yaitu:

1. Kepatuhan Formal meliputi:

Melaporkan SPT tepat waktu, melaporkan usaha ke Dirjen Pajak, melampirkan laporan keuangan dalam menghitung besar pajak penghasilan, pengurus atau direksi 
menandatangani SPT wajib pajak badan, melunasi pajak terutang tepat waktu, dan wajib pajak badan melakukan pembetulan SPT tahunan.

2. Kepatuhan Materiil meliputi:

Mengisi SPT dengan jujur, lengkap, benar dan melaporkannya ke KPP tepat waktu.

Indikator dari setiap variabel di atas dijadikan dasar untuk menyusun daftar pertanyaan yang diberikan kepada responden. Data yang terkumpul melalui daftar pertanyaan merupakan data kualitatif kemudian selanjutnya diubah menjadi data kuantitatif dengan cara pemberian nilai pada masing-masing jawaban, terdapat 5 skala tingkatan nilai yaitu :

$5=$ Sangat Setuju $(\mathrm{SS})$

$4=$ Setuju $(\mathrm{S})$

3 = Cukup Setuju (CS)

$2=$ Tidak Setuju (TS)

$1=$ Sangat Tidak Setuju $($ STS $)$

Berikut merupakan indikator yang digunakan dapat dilihat pada tabel 1 di bawah ini:

Tabel 1Skala Pengukuran Variabel Penelitian

\begin{tabular}{|c|l|l|c|}
\hline Variabel & \multicolumn{1}{|c|}{ Indikator Pernyataan } & \multicolumn{1}{c|}{ Item Pernyataan } & Skala \\
\hline \multirow{2}{*}{$(\mathrm{X})$} & Keakuratan & $1,4,11,15$ & Interval \\
\cline { 2 - 4 } & Ketepatan & 10 & Interval \\
\cline { 2 - 4 } & Relevansi & 8 & Interval \\
\cline { 2 - 4 } & Dapat dipercaya & 6 & Interval \\
\cline { 2 - 4 } & Kemudahan & $7,12,13,14$ & Interval \\
\cline { 2 - 4 } & Efisiensi & $2,3,5,9$ & Interval \\
\hline \multirow{2}{*}{$(\mathrm{Y})$} & Kepatuhan Formal & $1,3,4,5,6,8,12,13,15$ & Interval \\
\cline { 2 - 4 } & Kepatuhan Materiil & $2,7,9,10,11,14$ & Interval \\
\hline
\end{tabular}

\subsection{Metode Analisis Data}

Setelah melakukan pengumpulan data, maka dilakukan suatu analisis untuk mengolah data lebih lanjut dan melakukan pengujian terhadap hipotesa untuk mendapatkan pemecahan terhadap permasalahan dalam penelitian ini. Metode penelitian yang akan digunakan adalah:

\section{Analisis Kuantitatif}

Pada analisis kuantitatif akan menganalisis Pengaruh Pemahaman MPN (X) terhadap Tingkat Kepatuhan Wajib Pajak (Y) dengan menggunakan persamaan regresi linier sederhana, karena variabel bebas hanya satu dan penulis ingin melihat bagaimana pengaruh variabel bebas terhadap variabel terikat. Dalam analisis regresi sederhana ini, hubungan fungsional antara variabel bebas $(\mathbf{X})$ dengan variabel terikat $(\mathbf{Y})$ dinyatakan dengan model :

$\mathbf{Y}=\mathbf{a}+\mathbf{b X}$

Keterangan:

$\mathbf{a}=$ Konstanta

b $=$ Koefisien Parameter $\mathrm{X}$ atau koefisien regresi 
Langkah - langkah analisis:

1. Menentukan nilai a dan $\mathbf{b}$ dari model persamaan $\mathbf{Y}=\mathbf{a}+\mathbf{b X}$, dimana "a" adalah konstanta dan "b" adalah koefisien parameter X atau koefisien regresi.

2. Melakukan uji statistik, uji statistik dilakukan untuk menguji signifikansi koefisien regresi yang diperoleh. Langkah-langkah untuk melakukan uji t adalah:

\section{Uji hipotesis}

Dasar pengambilan keputusan adalah dengan membandingkan nilai $\mathbf{t}_{\text {hitung }}$ dengan $\mathbf{t}_{\text {tabel }} /$ Pvalue, dan $\mathbf{F}_{\text {hitung }}$ dengan $\mathbf{F}_{\text {tabel }} /$ Pvalue.

- Jika statistik $\mathbf{t}_{\text {hitung }}>\mathbf{t}_{\text {tabel }}$, maka $\mathbf{H o}$ dinyatakan ditolak.

- Jika statistik $\mathbf{t}_{\text {hitung }}<\mathbf{t}_{\text {tabel}}$, maka $\mathbf{H o}$ dinyatakan gagal ditolak.

\section{Taraf Signifikansi}

Uji signifikansi ini menggunakan $\boldsymbol{\alpha}$ sebesar 5\% dan df (derajat kebebasan)= jumlah data - uji t dilakukan 1 sisi.

\section{Uji statistik}

Membandingkan antara statistik $\mathbf{t}_{\text {hitung }}$ dengan $\mathbf{t}_{\text {tabel }}$, maka kesimpulan dapat diambil, apakah Ho dinyatakan ditolak atau gagal ditolak.

Membandingkan antara statistik $\mathbf{F}_{\text {hitung }}$ dengan $\mathbf{F}_{\text {tabel }}$, maka kesimpulan dapat diambil, apakah Ho dinyatakan ditolak atau gagal ditolak.

\section{HASIL DAN PEMBAHASAN}

\subsection{Pemahaman Wajib Pajak Terhadap Modul Penerimaan Negara (MPN)}

Wajib pajak dituntut untuk dapat memahami Modul Penerimaan Negara (MPN) karena MPN merupakan suatu modul yang memilki keakuratan, ketepatan, relevansi, dapat dipercaya, memberikan kemudahan dan efisien. Untuk mengetahui sejauh mana Pemahaman Modul Penerimaan Negara (MPN), maka dibuatlah kategorisasi dari hasil perhitungan item pernyataan kedalam 5 indikator berikut:
1. $20 \%-35 \%$
Sangat Kurang Memahami (SKM)
2. $36 \%-51 \%$
Kurang Memahami (KM)
3. $52 \%-67 \%$
Cukup Memahami (CM)
4. $68 \%-83 \%$
Memahami (M)
5. $84 \%-100 \%$
Sangat Memahami (SM)

Tabel .Tanggapan Responden Mengenai Pemahaman Terhadap Modul Penerimaan Negara (MPN)

\begin{tabular}{|l|l|l|l|l|}
\hline \multicolumn{1}{|c|}{ Keterangan } & \multicolumn{1}{|c|}{$\begin{array}{c}\text { Score } \\
\text { Real }\end{array}$} & $\begin{array}{c}\text { Score } \\
\text { Max }\end{array}$ & \multicolumn{1}{|c|}{ Persentase (\%) } & \multicolumn{1}{|c|}{ Kategori } \\
\hline $\begin{array}{l}\text { Modul Penerimaan } \\
\text { Negara (MPN) }\end{array}$ & $\mathbf{1 9 2 4}$ & $\mathbf{2 6 2 5}$ & $\mathbf{7 3 , 3}$ & Memahami \\
\hline
\end{tabular}

Sumber: Data diolah dari hasil kuesioner 2012

Berdasarkan di atas dapat disimpulkan bahwa tanggapan responden mengenai pemahaman Modul Penerimaan Negara (MPN) berada pada kategori memahami. Pemahaman mengenai Modul Penerimaan Negara (MPN) berada pada tingkat 73,3\%. 
Secara keseluruhan pemahaman wajib pajak mengenai Modul Penerimaan Negara (MPN) sudah baik tetapi masih belum optimal. Berikut pemahaman wajib pajak badan pada setiap indikator dan pernyataan dari Modul Penerimaan Negara (MPN).

Tabel . Pemahaman Wajib Pajak Terhadap Indikator Modul Penerimaan Negara (MPN)

\begin{tabular}{|c|c|c|c|c|c|}
\hline \multirow{2}{*}{ Variabel } & Indikator & $\begin{array}{c}\text { Score } \\
\text { Real }\end{array}$ & $\begin{array}{c}\text { Score } \\
\text { Max }\end{array}$ & $\begin{array}{c}\text { Persentase } \\
\mathbf{( \% )}\end{array}$ & Kategori \\
\hline Pemahaman MPN & Keakuratan & 525 & 700 & $75 \%$ & $\mathrm{M}$ \\
\cline { 2 - 6 } & Ketepatan & 122 & 175 & $69.7 \%$ & $\mathrm{M}$ \\
\cline { 2 - 6 } & Relevansi & 126 & 175 & $72 \%$ & $\mathrm{M}$ \\
\cline { 2 - 6 } & Dapat Dipercaya & 126 & 175 & $72 \%$ & $\mathrm{M}$ \\
\cline { 2 - 6 } & Kemudahan & 496 & 700 & $70.9 \%$ & $\mathrm{M}$ \\
\cline { 2 - 6 } & Efisiensi & 529 & 700 & $75.6 \%$ & $\mathrm{M}$ \\
\cline { 2 - 6 } & Jumlah & $\mathbf{1 9 2 4}$ & $\mathbf{2 6 2 5}$ & $\mathbf{7 3 . 3 \%}$ & $\mathbf{M}$ \\
\hline
\end{tabular}

Sumber: Data Diolah dari hasil kuesioner 2012

Berdasarkan tabel diatas, dilihat dari indikator menunjukan bahwa pemahaman mengenai efisiensi yang tertinggi dan berada pada kategori memahami dengan tingkat pemahaman $75,6 \%$. Indikator keakuratan berada pada kategori memahami dengan tingkat pemahaman $75 \%$. Indikator relevansi dan dapat dipercaya keduanya berada pada kategori memahami dengan tingkat pemahaman $72 \%$. Indikator kemudahan berada pada kategori memahami dengan tingkat pemahaman 70,9\%. Sedangkan Indikator ketepatan berada pada kategori memahami dengan tingkat pemahaman $69,7 \%$.

\section{Hubungan Tingkat Pendidikan Terhadap Pemahaman Wajib Pajak}

Berdasarkan dari deskripsi responden mengenai tingkat pendidikan terakhir dapat dijelaskan bahwa tingkat pendidikan responden yaitu Strata 1 (S1) sebesar 65,7\% secara keseluruhan memberikan dampak akan tingkat pemahaman terhadap Modul Penerimaan Negara (MPN) berada pada kategori memahami. Dengan begitu dapat dijelaskan bahwa tingkat pendidikan yang tinggi yang dimiliki oleh wajib pajak mendukung suatu pemahaman yang tinggi juga bagi wajib pajak. Hal ini dikarenakan mereka yang memiliki pendidikan yang tinggi memiliki wawasan dan pengetahuan yang cukup luas.

\section{Tingkat Kepatuhan Wajib Pajak Pada KPP Pratama Kedaton}

Wajib pajak dituntut patuh dalam membayar pajak karena membayar pajak merupakan kewajiban bagi setiap wajib pajak. Kepatuhan pajak dibagi menjadi 2 yaitu, kepatuhan formal dan kepatuhan materiil. Untuk mengetahui sejauh mana tingkat kepatuhan wajib pajak, maka dibuatlah kategorisasi dari hasil perhitungan item pernyataan kedalam 5 indikator berikut:
1. $20 \%-35 \%$
Sangat Kurang Patuh (SKP)
2. $36 \%-51 \%$
Kurang Patuh (KP)
3. $52 \%-67 \%$
Cukup Patuh (CP)
4. $68 \%-83 \%$
Patuh (P)
5. $84 \%-100 \%$
Sangat Patuh (SP) 
Tabel . Tanggapan Responden Mengenai Tingkat Kepatuhan Wajib Pajak Pada KPP Pratama Kedaton

\begin{tabular}{|c|c|c|c|c|}
\hline Keterangan & $\begin{array}{c}\text { Score } \\
\text { Real }\end{array}$ & $\begin{array}{c}\text { Score } \\
\text { Max }\end{array}$ & Persentase (\%) & Kategori \\
\hline $\begin{array}{c}\text { Tingkat Kepatuhan } \\
\text { Wajib Pajak }\end{array}$ & $\mathbf{1 8 6 5}$ & $\mathbf{2 6 2 5}$ & $\mathbf{7 1 , 1}$ & Patuh \\
\hline
\end{tabular}

Berdasarkan tabel diatas, dilihat dari indikator menunjukan bahwa pemahaman mengenai efisiensi yang tertinggi dan berada pada kategori memahami dengan tingkat pemahaman $75,6 \%$. Indikator keakuratan berada pada kategori memahami dengan tingkat pemahaman $75 \%$. Indikator relevansi dan dapat dipercaya keduanya berada pada kategori memahami dengan tingkat pemahaman $72 \%$. Indikator kemudahan berada pada kategori memahami dengan tingkat pemahaman 70,9\%. Sedangkan Indikator ketepatan berada pada kategori memahami dengan tingkat pemahaman $69,7 \%$.

Tabel .Tingkat Kepatuhan Wajib Pajak Dilihat Dari Indikator Kepatuhan Formal dan Materiil

\begin{tabular}{|c|c|c|c|c|c|}
\hline Variabel & Indikator & $\begin{array}{c}\text { Score } \\
\text { Real }\end{array}$ & $\begin{array}{c}\text { Score } \\
\text { Max }\end{array}$ & $\begin{array}{c}\text { Persentase } \\
(\mathbf{\%})\end{array}$ & Kategori \\
\hline $\begin{array}{c}\text { Tingkat } \\
\text { Kepatuhan } \\
\text { Wajib Pajak }\end{array}$ & $\begin{array}{c}\text { Kepatuhan } \\
\text { Formal }\end{array}$ & 1117 & 1575 & $71 \%$ & $\mathrm{P}$ \\
\cline { 2 - 6 } & $\begin{array}{c}\text { Kepatuhan } \\
\text { Materiil }\end{array}$ & 748 & 1050 & $71,2 \%$ & $\mathrm{P}$ \\
\cline { 2 - 6 } & Jumlah & $\mathbf{1 8 6 5}$ & $\mathbf{2 6 2 5}$ & $\mathbf{7 1 , 1 \%}$ & $\mathbf{P}$ \\
\hline
\end{tabular}

Sumber: Data diolah dari hasil kuesioner 2012

Berdasarkan tabel diatas, dilihat dari indikator menunjukan bahwa kepatuhan formal berada pada kategori patuh dengan tingkat kepatuhan $71 \%$. Sedangkan indikator kepatuhan materiil berada pada kategori patuh dengan tingkat kepatuhan $71,2 \%$.

\section{Hubungan Tingkat Pendidikan Terhadap Tingkat Kepatuhan Wajib Pajak}

Berdasarkan dari deskripsi responden mengenai tingkat pendidikan terakhir dapat dijelaskan bahwa tingkat pendidikan responden yaitu Strata 1 (S1) sebesar 71,1\% secara keseluruhan memberikan dampak akan tingkat kepatuhan wajib pajak yang berada pada kategori patuh. Dengan begitu dapat dijelaskan bahwa tingkat pendidikan yang tinggi yang dimiliki oleh wajib pajak dapat meningkatkan kepatuhan wajib pajak. Hal ini disebabkan karena mereka yang memiliki tingkat pendidikan yang tinggi memiliki pengetahuan yang lebih baik dan wawasan lebih banyak dalam hal pajak sehingga wajib pajak mempunyai kesadaran yang lebih dalam mematuhi perundang-undangan pajak yang berlaku sehingga dengan begitu tingkat kepatuhan wajib pajak dapat meningkat.

\subsection{Analisis Data}

\section{Analisis Regresi Linier Sederhana}

Analisis regresi linier sederhana digunakan untuk mengetahui pengaruh variabel bebas (variabel independent) terhadap variabel terikat (variabel dependent). Variabel bebas dalam penelitian ini adalah pemahaman MPN (X), sedangkan variabel terikatnya adalah tingkat kepatuhan wajib pajak (Y). 
Pengaruh Pemahaman Modul Penerimaan Negara (MPN) Terhadap Tingkat Kepatuhan Wajib Pajak

\begin{tabular}{|cc|c|c|c|c|c|}
\hline \multirow{2}{*}{ Model } & \multicolumn{2}{|c|}{$\begin{array}{c}\text { Unstandardized } \\
\text { Coefficients }\end{array}$} & \multirow{2}{*}{$\begin{array}{c}\text { Standardized } \\
\text { Coefficients }\end{array}$} & \multirow{2}{*}{$\mathrm{t}$} & \multirow{2}{*}{ Sig. } \\
\cline { 3 - 5 } & B & Std. Error & Beta & & \\
\hline \multirow{2}{*}{1} & (Constant) & 9,338 & 7,211 & & 1,295 &, 204 \\
& Pemahaman MPN &, 799 &, 131 &, 729 & 6,121 &, 000 \\
\hline
\end{tabular}

Berdasarkan output yang dihasilkan oleh SPSS for windows versi 18.0 diperoleh persamaan regresi sebagai berikut:

$$
\begin{aligned}
& Y=\mathbf{a}+\mathbf{b X} \\
& Y=9,338+0,799 X
\end{aligned}
$$

Berdasarkan persamaan regresi diatas dengan nilai konstanta 9,338 dan koefisien regresi 0,799, dapat diinterprestasikan ada pengaruh yang signifikan pemahaman MPN terhadap tingkat kepatuhan wajib pajak. Dari persamaan tersebut diatas dapat diartikan jika terdapat kenaikan 1 point dari pemahaman MPN maka akan terjadi peningkatan terhadap kepatuhan wajib pajak sebesar 0,799 pada konstanta sebesar 9,338. Jika tidak terjadi perubahan/ tingkat pemahaman tetap maka besarnya tingkat kepatuhan wajib pajak sebesar 9,338 .

\section{Analisis Hubungan Pemahaman MPN Terhadap Tingkat Kepatuhan Wajib Pajak}

\begin{tabular}{|c|c|c|c|c|}
\hline Model & $\mathrm{R}$ & $\mathrm{R}$ Square & Adjusted R Square & Std. Error of the Estimate \\
\hline 1 &, $729^{\mathrm{a}}$ &, 532 &, 517 & 3,94242 \\
\hline
\end{tabular}

Berdasarkan tabel 4.10 dapat dietahui koefisien korelasi sebesar 0,729 yang berarti hubungan antara variabel $X$ yaitu pemahaman Modul Penerimaan Negara (MPN) berpengaruh positif terhadap tingkat kepatuhan wajib pajak. Sedangkan dilihat dari koefisien penentu nya $\mathrm{KP}=0,532$ atau $53.2 \%$ yang artinya besarnya kontribusi / sumbangan variabel $\mathrm{X}$ yaitu pemahaman MPN terhadap tingkat kepatuhan wajib pajak. Sedangkan sisanya sebesar 46.8\% merupakan pengaruh dari faktor lain. Dengan demikian dapat ditarik kesimpulan Pemahaman Modul Penerimaan Negara (MPN) memberikan pengaruh yang positif dan memberikan kontribusi yang besar terhadap tingkat kepatuhan wajib pajak pada KPP Pratama Kedaton.

\begin{tabular}{|cc|c|c|c|c|c|}
\hline \multicolumn{1}{|c|}{ Model } & Sum of Squares & df & Mean Square & F & Sig. \\
\hline 1 & Regression & 582,236 & 1 & 582,236 & 37,461 &, $000^{\text {a }}$ \\
& Residual & 512,907 & 33 & 15,543 & & \\
& Total & 1095,143 & 34 & & & \\
\hline
\end{tabular}


Berdasarkan hipotesis yang telah dikemukakan yaitu :

Ho = Pemahaman Modul Penerimaan Negara (MPN) (Variabel X) tidak berpengaruh positif terhadap tingkat kepatuhan wajib pajak (Variabel Y).

Hipotesis diatas dapat dilakukan pengujian dengan kriteria sebagai berikut:

Uji T

Apabila $\mathbf{t}_{\text {hitung }}>\mathbf{t}_{\text {tabel }}$, maka Ho dinyatakan ditolak / P value

Apabila $\mathbf{t}_{\text {hitung }}<\mathbf{t}_{\text {tabel }}$, maka Ho dinyatakan gagal ditolak / P value

\section{Uji F}

Apabila $\mathbf{F}_{\text {hitung }}>\mathbf{F}_{\text {tabel }}$, maka $\mathbf{H o}$ dinyatakan ditolak / P value

Apabila $\mathbf{F}_{\text {hitung }}<\mathbf{F t}_{\text {abel }}$, maka $\mathbf{H o}$ dinyatakan gagal ditolak / P value

Berdasarkan tabel diatas didapat $\mathrm{t}_{\text {hitung }}$ sebesar 6,121 lebih besar dari $\mathrm{P}$ value sebesar 0,204. Dengan taraf pengujian $\alpha$ sebesar $0,05(5 \%)$ kemudian didapat taraf signifikansi sebesar 95\%. Dengan demikian diambil kesimpulan Ho dinyatakan ditolak.

Berdasarkan tabel diatas dengan melakukan uji $\mathrm{F}$ didapat $\mathrm{F}_{\text {hitung }}$ sebesar 37,461 lebih besar dari Pvalue sebesar 0,000. Dengan demikian diambil kesimpulan Ho dinyatakan ditolak.

Dengan demikian dari hasil uji $\mathrm{T}$ dan uji $\mathrm{F}$ dapat dikemukakan bahwa hipotesis yang penulis ajukan terbukti dan benar apa adanya.

\section{KESIMPULAN DAN SARAN}

\subsection{Kesimpulan}

Dari hasil analisis yang telah dilakukan dapat di ambil kesimpulan sebagai berikut:

a. Secara keseluruhan pemahaman wajib pajak yang terdaftar pada KPP Pratama Kedaton terhadap Modul Penerimaan Negara (MPN) memiliki pemahaman yang baik tetapi masih belum optimal.

b. Tingkat kepatuhan wajib pajak yang terdaftar pada KPP Pratama Kedaton menunjukan tingkat kepatuhan yang baik tetapi masih harus ditingkatkan lagi.

c. Pemahaman wajib pajak terhadap Modul Penerimaan Negara (MPN) berpengaruh positif terhadap tingkat kepatuhan wajib pajaknya. Ini dapat dilihat dari koefisien penentu yang sebesar 53,2\% yang artinya besarnya kontribusi atau sumbangan variabel $\mathrm{X}$ yaitu pemahaman MPN terhadap tingkat kepatuhan wajib pajak yang terdaftar pada KPP Pratama Kedaton cukup tinggi. Sedangkan sisanya sebesar 46,8\% berasal dari faktor-faktor lain seperti sanksi - sanksi yang diberikan, kemudahan dalam membayar pajak, dll.

d. Pemahaman wajib pajak dan tingkat kepatuhan wajib pajak dipengaruhi oleh tingkat pendidikan wajib pajak itu sendiri. Semakin tinggi tingkat pendidikan wajib pajak maka semakin memiliki tingkat pemahaman yang baik dan tingkat kepatuhan yang besar pula, demikian sebaliknya.

\subsection{Saran}

Berdasarkan kesimpulan yang ada penulis mengajukan saran sebagai berikut:

a. Meningkatkan sosialisasi MPN bagi wajib pajak karena MPN dapat memberikan kontribusi yang cukup besar dalam meningkatkan kepatuhan wajib pajak dalam membayar pajak. 
b. Memberikan sanksi-sanksi yang tegas bagi wajib pajak yang "nakal" sehingga dapat memberikan efek jera bagi wajib pajak.

c. Memberikan pelayanan pajak yang baik bagi wajib pajak sehingga wajib pajak dapat merasa mudah dan nyaman dalam membayar pajak.

d. Menyelenggarakan pelatihan-pelatihan perpajakan sehingga wajib pajak memiliki pengetahuan yang lebih baik sehingga mendorong tingkat kepatuhan wajib pajak dan pemahaman wajib pajak terhadap MPN.

\section{DAFTAR PUSTAKA}

Mardiasmo, Dr., MBA, Ak. 2001. Perpajakan. Yogyakarta: Andi Yogyakarta.

Mulyani Indrawati, Sri. Peraturan Menteri Keuangan No-99/PMK.06/2006 tentang Modul Penerimaan Negara. Jakarta.

Mulyani Indrawati, Sri. Peraturan Menteri Keuangan No. 544/KMK.04/2000 tentang Kriteria Kepatuhan Wajib Pajak. Jakarta.

Nurmantu, Safri. 2003. Dasar-Dasar Perpajakan. Jakarta: IND-HILL.

Peraturan Dirjen Perbendaharaan Nomor PER-78/PB/2006 tentang Penataan Penerimaan Negara Melalui Modul Penerimaan Negara.

Peraturan Dirjen Pajak Nomor PER-148/PJ/2007 tentang Pelaksanaan Modul Penerimaan Negara.

Purbopranoto, Kuncoro. 2007. Setengah Abad Bahasa Indonesia. Jakarta: Idayu.

Purnomo, Hadi. 2005. Mengawali Reformasi Perpajakan. Jakarta: Ditjen Pajak Departemen Keuangan.

Santosa, Purbayu Budi dan Azhari, 2005. Analisis Statistik Dengan Microsoft Excel dan SPSS. Yogyakarta: Andi Yogyakarta.

Soemitro, H. Rochmat. 1998. Azas dan Dasar Perpajakan I. Refika Aditama.

YS. Chaniago, Amran. 2002. Kamus Lengkap Bahasa Indonesia. Bandung: Pustaka Setia.

Zain, Mohammad. 2004. Manajemen Perpajakan. Jakarta: Salemba Empat.

\section{Sumber website:}

www.bisnis-sumatera.com

$\underline{w w w . d j p k . c o m}$

www.ortag.org

www.perbendaharaan.go.id 